\title{
Multiple Roles for Cytokines in Atopic Dermatitis: From Pathogenic Mediators to Endotype-Specific Biomarkers to Therapeutic Targets
}

\author{
Luca Fania ${ }^{1,+}$, Gaia Moretta ${ }^{1,+} \mathbb{C}^{\mathbb{D}}$, Flaminia Antonelli ${ }^{1}$, Enrico Scala ${ }^{1} \mathbb{D}$, Damiano Abeni ${ }^{2}$, Cristina Albanesi ${ }^{3, * \mathbb{D}}$ \\ and Stefania Madonna ${ }^{3}$ (D) \\ 1 Integrated Center for Research in Atopic Dermatitis (CRI-DA), IDI-IRCCS, Via Monti di Creta, 104, \\ 00167 Rome, Italy; 1.fania@idi.it (L.F.); g.moretta@idi.it (G.M.); flamiantonelli@gmail.com (F.A.); \\ e.scala@idi.it (E.S.) \\ 2 Clinical Epidemiology Unit, IDI-IRCCS, 00167 Rome, Italy; d.abeni@idi.it \\ 3 Laboratory of Experimental Immunology, IDI-IRCCS, Via Monti di Creta, 104, 00167 Rome, Italy; \\ s.madonna@idi.it \\ * Correspondence: c.albanesi@idi.it \\ + These authors contributed equally to this work.
}

Citation: Fania, L.; Moretta, G.; Antonelli, F.; Scala, E.; Abeni, D.; Albanesi, C.; Madonna, S. Multiple Roles for Cytokines in Atopic Dermatitis: From Pathogenic Mediators to Endotype-Specific Biomarkers to Therapeutic Targets. Int. J. Mol. Sci. 2022, 23, 2684. https://doi.org/10.3390/ ijms23052684

Academic Editor: Naoko Kanda

Received: 7 February 2022

Accepted: 25 February 2022

Published: 28 February 2022

Publisher's Note: MDPI stays neutral with regard to jurisdictional claims in published maps and institutional affiliations.

Copyright: (c) 2022 by the authors Licensee MDPI, Basel, Switzerland. This article is an open access article distributed under the terms and conditions of the Creative Commons Attribution (CC BY) license (https:// creativecommons.org/licenses/by/ $4.0 /)$.

\begin{abstract}
Atopic dermatitis (AD) is one of the most common chronic inflammatory skin diseases, which generally presents with intense itching and recurrent eczematous lesions. AD affects up to $20 \%$ of children and $10 \%$ of adults in high-income countries. The prevalence and incidence of AD have increased in recent years. The onset of AD mostly occurs in childhood, although in some cases AD may persist in adult life or even manifest in middle age (adult-onset AD). AD pathophysiology is made of a complex net, in which genetic background, skin barrier dysfunction, innate and adaptive immune responses, as well as itch contribute to disease development, progression, and chronicization. One of the most important features of $\mathrm{AD}$ is skin dehydration, which is mainly caused by filaggrin mutations that determine trans-epidermal water loss, $\mathrm{pH}$ alterations, and antigen penetration. In accordance with the "outside-inside" theory of AD pathogenesis, in a context of an altered epidermal barrier, antigens encounter epidermal antigen presentation cells (APCs), such as epidermal Langerhans cells and inflammatory epidermal dendritic cells, leading to their maturation and Th-2 cell-mediated inflammation. APCs also bear trimeric high-affinity receptors for immunoglobulin E (IgE), which induce IgE-mediated sensitizations as part of pathogenic mechanisms leading to AD. In this review, we discuss the role of cytokines in the pathogenesis of $\mathrm{AD}$, considering patients with various clinical $\mathrm{AD}$ phenotypes. Moreover, we describe the cytokine patterns in patients with AD at different phases of the disease evolution, as well as in relation to different phenotypes/endotypes, including age, race, and intrinsic/extrinsic subtypes. We also discuss the outcomes of current biologics for AD, which corroborate the presence of multiple cytokine axes involved in the background of AD. A deep insight into the correlation between cytokine patterns and the related clinical forms of AD is a crucial step towards increasingly personalized, and therefore more efficient therapy.
\end{abstract}

Keywords: atopic dermatitis; cytokines; intracellular pathways; endotypes; itch; biologics; small-molecule inhibitors

\section{Introduction}

Atopic dermatitis (AD) is one of the most common chronic inflammatory skin diseases, characterized by intense itching and recurrent eczematous lesions [1]. The prevalence and incidence of AD have increased in recent years [1]. According to the Global Burden of Disease Study, the prevalence in high-income countries is between $15 \%$ and $20 \%$ among children, and up to $10 \%$ among adults $[2,3]$. No gender-related differences are reported, while for ethnicity a higher prevalence was observed in Afro-American U.S. children (19.3\%) 
compared to Caucasians (16.8\%) [1]. The onset of AD mostly occurs in childhood, usually followed by remission before adulthood, although some cases may reveal protracted disease activity (persistent AD) or even a primary outbreak in middle age (adult-onset AD) [4] Several patients may also have an onset in childhood followed by a latency period with re-exacerbation in adulthood (chronic-relapsing form) or even, in a few cases, the first occurrence in adolescence (adolescent-onset AD).

$\mathrm{AD}$ is generally associated with other atopic diseases (atopic march), such as asthma, rhinitis, conjunctivitis, and food allergy, which further worsen quality of life [5,6]. Evidence of this association is provided by a study on Italian atopic schoolchildren [7], which reported a prevalence of asthma ranging from $46 \%$ in children with $\mathrm{AD}$ to $10 \%$ in unaffected ones, while the prevalence of allergic rhino-conjunctivitis in these population groups was $35.6 \%$ and $15.1 \%$, respectively. Besides, atopic patients have a major risk of developing respiratory, contact, or food allergies.

AD clinically manifests as the evolution from an initial acute phase, characterized by pruritus and erythemato-vesicles/papules, to a chronic phase, during which skin appears more lichenified as a consequence of tissue remodeling and dermal fibrosis due to inflammation and scratching of the skin [1]. Acute and chronic lesions are often found in the same individual, often overlap, and clinically are sometimes difficult to distinguish [8]. Rarely, a simultaneous occurrence of psoriasis and AD may be observed in the same patient, making the differential diagnosis even more complex [9].

AD pathophysiology is made of a complex net, in which genetic background, skin barrier dysfunction, innate and adaptive immune responses, and itch contribute to development, progression, and chronicitation of disease [3]. One of the most important markers of $\mathrm{AD}$ is skin dehydration, which is mainly caused by filaggrin (FLG) gene mutations that determine trans-epidermal water loss, $\mathrm{pH}$ alterations, and antigen penetration [10]. In accordance with the "outside-inside" theory of AD pathogenesis, in a context of an altered epidermal barrier, antigens encounter epidermal antigen presentation cells (APCs), such as epidermal Langerhans cells and inflammatory epidermal dendritic cells (IEDC), leading to their maturation and Th2-mediated inflammation. APCs also bear trimeric high-affinity receptors for immunoglobulin $\mathrm{E}$ (IgE), and therefore IgE-mediated sensitizations play an important role as part of pathogenic mechanisms leading to AD.

In this review, we discuss the role of cytokines in the pathogenesis of $\mathrm{AD}$ considering patients with various clinical AD phenotypes. Moreover, we describe the cytokine patterns in patients with $\mathrm{AD}$ at different phases of the disease evolution, as well as in relation to the different phenotypes/endotypes, including age, race, and intrinsic/extrinsic subtypes. We also discuss the outcomes of current biologics for $\mathrm{AD}$, which corroborate the concept that multiple cytokine axes act in the background of AD. A deep insight into the correlation between cytokine patterns and the related clinical forms of $\mathrm{AD}$ is the crucial step towards increasingly personalized, and therefore more efficient therapy.

\section{Active Participation of Inflammatory Cytokines during AD Evolution}

\subsection{Role of Cytokines in Acute $A D$}

$\mathrm{AD}$ disease is characterized by a biphasic inflammation, evolving from an initial, acute, Th2- and Th22-dominated phase to a chronic phase characterized by the concomitant presence of T helper (Th)1, Th2 cells, and Th17 cells [3]. Th2-derived cytokines, together with inflammatory mediators released by innate immune cells, such as mast cells, pathogenically contribute to the initiation and amplification of skin inflammation in AD lesions.

The role of the innate immune system in the early phase of $\mathrm{AD}$ has been demonstrated in experimental animal models [11,12] and is likely of clinical relevance in infancy [13].

A key player of innate immunity is the epidermal barrier and the loss-of-function FLG gene variants (R510X and 2282del4) that constitute a major predisposing factor for $\mathrm{AD}$ [14]. However, whether immune dysregulation results from skin barrier abnormalities, such as FLG lack, or it can be considered as the initial trigger leading to barrier deficiencies by downregulation of, for example, FLG gene expression, is still debated. A recent study 
indicates that $F L G$-deficiency renders skin equivalents more sensitive to the detrimental effects of IL-4 and IL-13 compared to skin equivalents with normal FLG expression, and therefore, defects in the epidermal barrier, skin permeability, and cutaneous innate immune response are not primarily linked to FLG gene deficiency but are rather secondarily induced by Th2 inflammation [15].

\subsubsection{IL-1 Cytokine Family}

Regarding the innate immune responses, dysregulation of the IL-1 axis may account for the initiation of inflammatory responses in $\mathrm{AD}$ [16]. Indeed, an up-regulated expression of the IL-1-related cytokines IL- $1 \beta$ and IL-18 was observed in AD patients with FLG mutation. These cytokines promote lead to cutaneous inflammation through the induction of secondary cytokines, such as IL-8, and upregulation of endothelial adhesion molecules [16]. IL- $1 \alpha$ is a pro-inflammatory cytokine released by keratinocytes after injury and by skin dysbiosis [17]. As one of the first and most important mediators in antigen presentation and induction of the inflammatory cascade, IL- $1 \alpha$ has been considered as a therapeutic target in AD.

Similarly, IL-33, a cytokine structurally related to IL-1 $\beta$ and IL-18, is abundant in the epidermis of AD lesions [18,19]. However, it is unclear whether IL-33 is the cause or the result of $\mathrm{AD}$. Of note, when up-regulated in keratinocytes of a transgenic mouse model, IL-33 induces severe eczema [20]. IL-33 is produced by endothelial cells and various epithelial cells, including keratinocytes, which constitutively express IL-33 as an inactive precursor [19]. In response to infection or tissue injury, IL-33 precursor is cleaved by caspase- 1 to form an active secreted IL-33, which in turn activates mast cells, basophils, and group 2 innate lymphoid cells (ILC2) to secrete IL-4, IL-5, and IL-13 via the receptor suppression of tumorigenicity 2 (ST2) [21]. Other than triggering Th2 polarization, IL-33 promotes the secretion of pruritic cytokines, including TSLP and IL-31, from keratinocytes and Th2 cells, respectively, which amplifies Th2 responses [21,22]. IL-33 also mediates the itch response by activating itch-sensing sensory neurons [19] and contributes to the disruption of the epidermal barrier function via the down-regulation of FLG and claudin-1 levels [23] (Figure 1).

Danger signals from barrier disruption and microbial invasion trigger the production of additional keratinocyte-derived cytokines, such as IL-6, IL-23, and tumor necrosis factor (TNF)- $\alpha$, which exhibit pro-inflammatory activities and promote the activation, differentiation, and recruitment of inflammatory cells to skin lesions [24-27]. The combination of IL-1 $\beta$ and IL- 6 , together with transforming growth factor- $\beta$ (TGF- $\beta$ ), promotes Th17 cell activation, which plays an important part in early stages of $\mathrm{AD}$ [28].

IL-36 cytokines are other innate immunity players belonging to the IL-1 family that are upregulated in the skin of acute and chronic AD. Interestingly, colonization with S. aureus in a murine AD model induces inflammation through IL-36R- and IL-1R-dependent signaling [29].

In acute phases of $\mathrm{AD}$, keratinocytes in barrier-disrupted epidermis also produce large amounts of thymic stromal lymphopoietin (TSLP) and interleukin (IL)-25, which promote Th2 immune deviation via OXO40L/OX40 signaling [30].

\subsubsection{TSLP}

TSLP is an epithelial cell-derived IL-7-like cytokine that is released in response to mechanical injury, microbial infection, and allergen exposure [21]. Increased expression of TSLP was observed in FLG-depleted keratinocytes after TLR-3, TLR-5, and TLR-2/-6 ligand stimulation [30]. The expression of TSLP in AD skin correlates with the severity of the disease and the degree of epidermal barrier disruption [31]. TSLP directly activates dendritic cells to polarize naive T cells towards Th2 cells that secrete IL-4, IL-5, and IL-13, which further induce TSLP release by keratinocytes themselves [32,33]. 


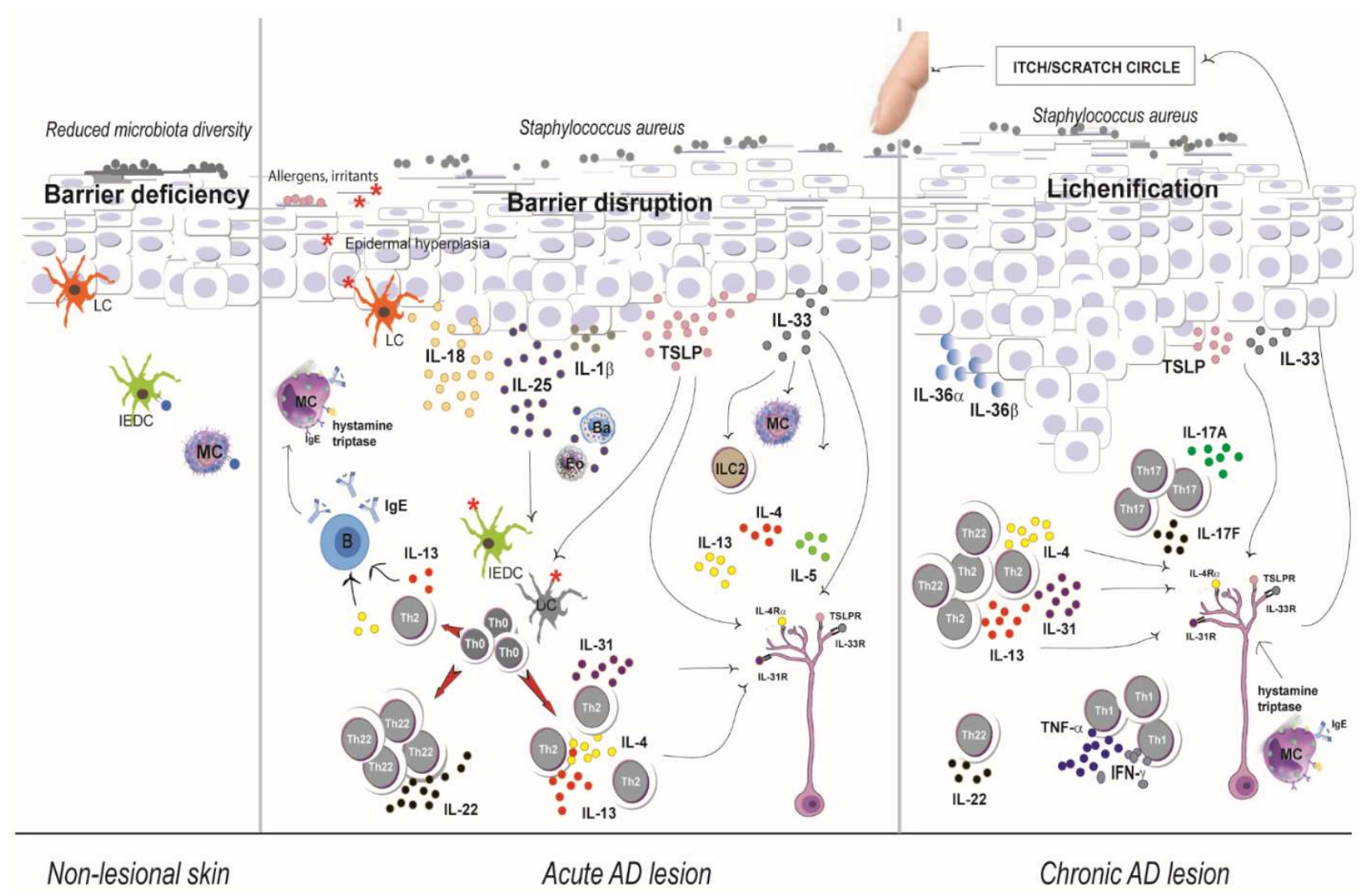

Figure 1. A simplistic overview of AD pathogenesis. Non-lesional skin has an epidermal barrier deficiency with a reduced diversity of the microbiome. In acute AD lesion, Langerhans cells, IEDC bearing specific IgE bound to the high affinity receptor for IgE, and dermal dendritic cells bind allergens and antigens. Keratinocyte-derived (IL-18, IL-1 $\beta$, IL-33, TSLP and IL-25) and Th2-cellderived cytokines IL-4, IL-13, and IL-31 directly activate sensory nerves, which promotes pruritus. During transition to chronicity, itch is amplified by various pruritogens (e.g., antigens and molecular mediators such as histamine and other substances). Scratching exacerbates dermatitis, which may further enhance pruritus and result in an itch/scratch vicious cycle. Chronic AD lesional skin is characterized by the intensification of Th2, Th1, and Th17 responses. DC = dendritic cell, MC = mast cell, IDEC = inflammatory dendritic epidermal cell, ILC = innate lymphoid cell. LC = lymphoid cell, $\mathrm{B}=\mathrm{B}$ cell, $\mathrm{Eo}=$ eosinophile, $\mathrm{Ba}=$ basophile, $\mathrm{IFN}=$ interferon, $\mathrm{IL}=$ interleukin, $\mathrm{Th}=\mathrm{T}$-helper cell, $\mathrm{Th} 0=$ naive $\mathrm{T}$ cell, $\mathrm{TNF}=$ tumor necrosis factor, $\mathrm{TSLP}=$ thymic stromal lymphopoietin.

TSLP also inhibits the production of antimicrobial peptides by keratinocytes, such as hBD-2, which correlates with the susceptibility of the skin to infections [34]. Furthermore, keratinocyte-derived TSLP contributes to pruritus induction by binding TSLP receptors located on cutaneous sensory neurons [35] (Figure 1).

\subsubsection{IL-17 Cytokine Family}

IL-25 is another key mediator of the development of Th2 response [36]. IL-25, also known as IL-17E, is a member of the IL-17 family, sharing structural similarity with other IL-17 members [36,37]. Although produced by several types of immune cells, such as allergen-activated mast cells, eosinophils, basophils, dermal dendritic cells, T cells, or ILC2, a vast amount of IL-25 derives from epithelial cells and in particular, by keratinocytes [37,38]. An increased number of IL-25-expressing epidermal keratinocytes was detected in lesional and non-lesional AD skin compared to the skin from healthy individuals [38]. IL-25 is known to induce Th2 cells via direct activation of naive CD4 ${ }^{+}$T cells or ILC2 activation to promote innate type-2 immune responses [37] (Figure 1). 


\subsubsection{Th2-Derived Cytokines}

$\mathrm{AD}$ is generally considered a Th2-mediated disease. In the acute phase, Th2 lymphocytes mount strong inflammatory responses with the secretion of type-2 cytokines, such as IL-4 and IL-13, which downregulate the levels of FLG, loricrin (LOR), and involucrin (INV) in keratinocytes, and exacerbates epidermal barrier dysfunction [10]. Keratinocytes constitutively express functional IL-4 and IL-13 receptors [39] and produce the eosinophil chemokine CCL26 in response to IL-4 and IL-13. Other than regulating IgE antibody production in B cells, IL-4 and IL-13 have been reported to act directly on itch-sensory neurons to promote itch $[40,41]$. Th2 cells also secrete IL-31, a pruritogenic cytokine described below (see Section 2.2).

\subsubsection{IL-22}

In addition to the strong Th2 activation, the acute $\mathrm{AD}$ lesions in adults are also characterized by a Th22 response, with release of IL-22 and S100A proteins [42,43]. Following scratching, the endogenous TLR-4 ligands stimulate the production of IL-23 from keratinocytes [44]. IL-23 in turn activates IL-23R-expressing DCs, which trigger Th22 immune response mediated by the aryl-hydrocarbon receptor (AHR) [45]. The robust IL-22 expression results in epidermal hyperplasia and barrier defects of affected skin [46] (Figure 1).

\subsection{Role of Cytokines in Chronic AD}

Although a Th2 signature predominates in the acute phase, a Th2 towards Th1 switch has been long deemed to promote disease chronicity [46,47].

More recent findings demonstrated that the progression of acute-to-chronic AD is associated with quantitative rather than qualitative changes in cytokine responses, with the intensification of Th2, Th1, and Th17 responses in chronic inflammation of AD [47]. Th17-related responses lead to the accumulation of IL-17A and IL-17F cytokines in chronic $\mathrm{AD}$ lesions. It is yet to be elucidated whether IL-17 plays a critical role in AD as it does in psoriasis.

In chronic $\mathrm{AD}$, lymphocyte-released cytokines synergize, thus amplifying the inflammatory responses. For example, in keratinocytes, IL-4 potentiates the action of IFN- $\gamma$ and TNF- $\alpha$ in inducing CXCR3 agonistic chemokines, such as CXCL9, CXCL10, and CXCL11, which recruit more T cells into inflamed skin [48].

The shift to chronic AD is also accompanied by increased activity of IL-36 cytokines [47] IL-36 cytokines are expressed predominantly by epidermal keratinocytes and act on many cells including endothelial and immune cells [49-51]. IL-36 cytokines do not act directly on $\mathrm{T}$ cells but instead can stimulate maturation and function of DCs and through them drive $T$ cell proliferation, thereby propagating and amplifying immune responses in the skin [52]. Recently, Shao et al. demonstrated that the serine-threonine kinase IRAK2 is the main intracellular effector of IL-36 and IL-1 cytokines in human keratinocytes, and its levels correlate with disease severity in AD and psoriasis [53] (Figure 1).

Chronic itch is the major symptom in AD patients [54,55]. Scratching exacerbates predisposing dermatitis, which may further enhance pruritus and result in an itch/scratch vicious cycle typically occurring in chronic $\mathrm{AD}$ [56].

Other than IL-33 and TLSP, IL-31 has also a pruritogenic activity through activation of the heterodimeric receptor IL-31 receptor A (IL31RA)/Oncostatin M receptor (OSMR $\beta$ ), expressed by dorsal root ganglia neurons, keratinocytes, and various innate immune cells [56]. IL-31 is a cytokine produced by various cells including Th2 cells, macrophages, dendritic cells, and eosinophils, and its levels were increased in lesional and non-lesional skin of AD patients [57-59]. In parallel, serum levels of IL-31 correlated with disease severity in AD patients $[60,61]$. Finally, in human AD skin, keratinocytes show elevated levels of IL31RA/OSMR $\beta$ expression resulting in stronger receptiveness to IL-31 [62]. In addition to its pruritogenic function, IL-31 is known to directly inhibit the differentiation of keratinocytes by downregulating the expression of barrier/differentiation-related proteins, which results in the disruption of epidermal barrier function [63-65] (Figure 1). 
A summary of the main cytokines involved in AD pathogenesis is reported in Table 1.

Table 1. Key biological effects of the main cytokines in AD pathogenesis.

\begin{tabular}{|c|c|c|c|}
\hline Cytokine & AD Phase & Function & Refs \\
\hline $\begin{array}{l}\text { IL-1 } \alpha, \text { IL-1 } \beta \\
\text { (IL-1 family) }\end{array}$ & Acute & $\begin{array}{l}\text { Promote the recruitment of leukocytes and regulate } \\
\text { synthesis of the extracellular lipid bilayers. }\end{array}$ & {$[16,17]$} \\
\hline $\begin{array}{l}\text { IL-33 } \\
\text { (IL-1 family) }\end{array}$ & Acute & $\begin{array}{l}\text { Activates mast cells, basophils, and ILC2; promotes } \\
\text { the secretion of pruritic cytokines, i.e., TSLP and } \\
\text { IL-31, from keratinocytes and Th2 cells, respectively. }\end{array}$ & [18-23] \\
\hline TSLP & Acute/Chronic & $\begin{array}{l}\text { Activates dendritic cells to polarize naive T cells } \\
\text { towards Th2 cells; induces pruritus by binding TSLP } \\
\text { receptors on cutaneous sensory neurons }\end{array}$ & {$[30-35]$} \\
\hline $\begin{array}{l}\text { IL-25 } \\
\text { (IL-17 family) }\end{array}$ & Acute/Chronic & $\begin{array}{c}\text { Induces innate and adaptive immune responses by } \\
\text { activating ILC2 or polarizing naive T cells } \\
\text { to Th2 cells. }\end{array}$ & {$[36,37]$} \\
\hline $\begin{array}{l}\text { IL-4/IL-13 } \\
\text { (Th2 cytokines) }\end{array}$ & Acute/Chronic & $\begin{array}{l}\text { Exacerbate epidermal barrier dysfunction; regulates } \\
\text { IgE antibody production in B cells; promotes itch } \\
\text { directly acting on sensory neurons. }\end{array}$ & {$[10,40,41]$} \\
\hline IL-22 & Acute & $\begin{array}{l}\text { Induces epidermal hyperplasia and barrier defects } \\
\text { of affected skin }\end{array}$ & [42-46] \\
\hline IL-17A, IL-17F (IL-17 family) & Chronic & $\begin{array}{c}\text { It is yet to be elucidated whether IL-17 plays a } \\
\text { critical role in AD. }\end{array}$ & {$[46,47]$} \\
\hline $\begin{array}{l}\text { IFN- } \gamma / \text { TNF- } \alpha \\
\text { (Th1 cytokines) }\end{array}$ & Chronic & $\begin{array}{l}\text { Induce CXCR3 agonistic chemokines, which recruit } \\
\text { more T cells into inflamed skin. }\end{array}$ & {$[48]$} \\
\hline $\begin{array}{c}\text { IL-36s } \\
\text { (IL-1 family) }\end{array}$ & Acute/Chronic & $\begin{array}{l}\text { Levels of IL-36 cytokines correlate with disease } \\
\text { severity in AD. }\end{array}$ & {$[52,53]$} \\
\hline IL-33 & Acute/Chronic & $\begin{array}{l}\text { Has pruritogenic activity; inhibits keratinocyte } \\
\text { differentiation by downregulating the expression of } \\
\text { barrier/differentiation-related proteins. }\end{array}$ & [56-65] \\
\hline
\end{tabular}

\section{Cytokines as Endotype-Specific Biomarkers}

$\mathrm{AD}$ is a heterogeneous disease with various clinical manifestations (phenotypes) sustained by specific molecular mechanisms (endotypes). Several endotypes based on the age of onset [66,67], ethnic origin [68], and clinical features can be distinguished [69,70].

\subsection{Age of $A D$ Onset}

Regarding the age of onset, early-onset (infantile $<2$ years, childhood 2-12 years, adolescent $12-18$ years) and adult onset (in patients aged $>18$ ) can be distinguished. Recently, a specific AD subtype has been identified to include elderly onset AD in patients aged $>60$ years.

Together with Th2 (IL-13, IL-31 and CCL17) activation, enhanced Th22 (IL-22 and S100As), Th17 (IL-17A, IL-19, CCL20, LL37 and peptidase inhibitor 3/elafin), and Th1 (IFN- $\gamma$ and CXCL9/CXCL10/CXCL11) pathways characterize adult AD, whereas pediatric patients exhibit lower Th1 activation but a higher expression of Th9 (IL-9), and innate markers (IL-1 $\beta$, IL-8 and IFN- $\alpha 1$ ), as well as dysfunctions in epidermal lipid metabolism responsible for the barrier alterations [71,72]. A recent study on tape strips from early-onset pediatric AD highlighted abnormalities in Th2-, Th22-, and Th17-related pathways also in non-lesional skin [73]. Non-lesional skin in pediatric patients with AD showed higher levels also of IL-19 and LL37, as well as of epidermal proliferation (Keratin 16 and S100As) markers [71] (Figure 2). 


\section{T-cell subsets and related cytokines in AD subtypes}

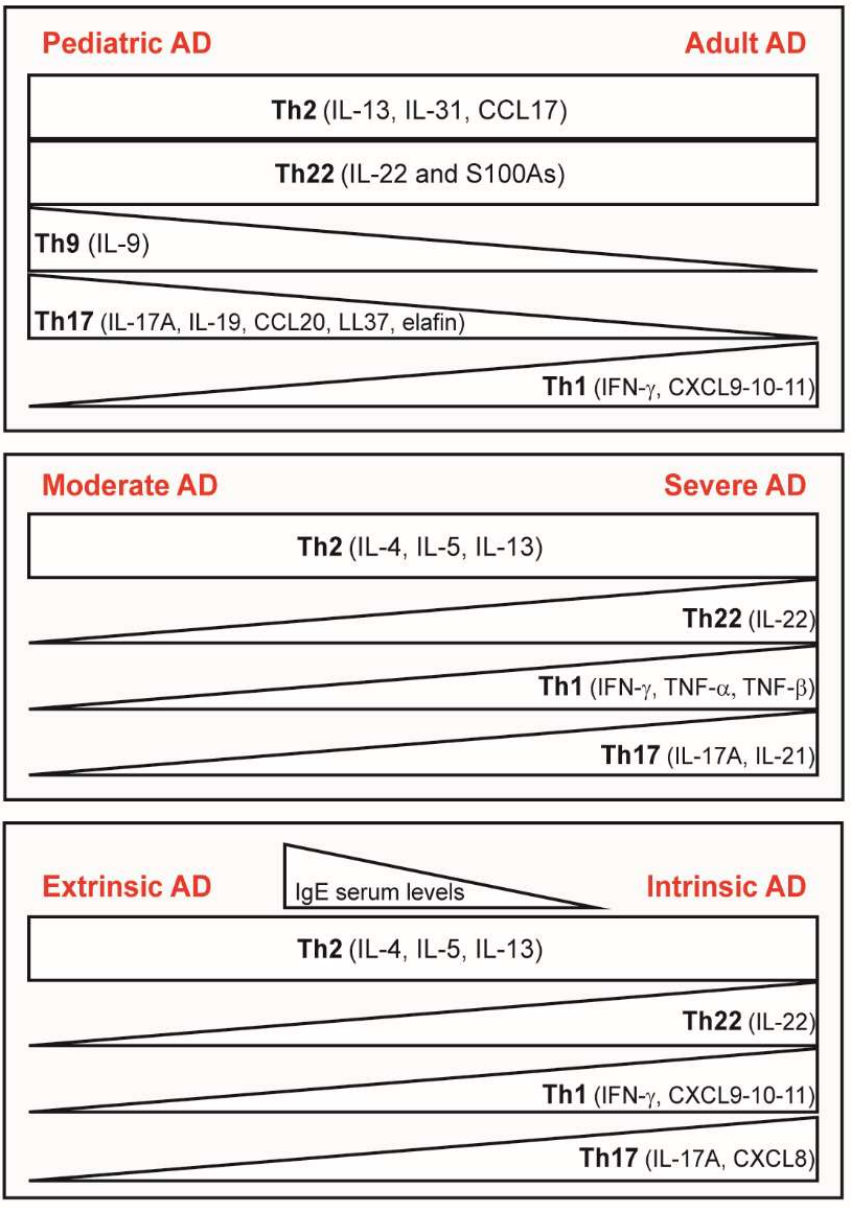

Figure 2. A schematic picture of the T cell subsets and cytokine profiles in the main AD endotypes. Adult $\mathrm{AD}$ is characterized by the intensification of Th1 signature, whereas pediatric AD shows the predominance of Th17(IL-17A, IL-19, CCL20, LL-37, elafin) and Th9 (IL-9)-related cytokines. Moderate and severe AD share Th2-dependent immune responses, with the identification of Th22 (IL-22), Th1 (IFN- $\gamma$, TNF-a, TNF- $\beta$ ), and Th17 (IL-17A and IL-21)-related cytokines in severe AD. Patients with extrinsic AD tend to exhibit barrier disruption, which causes repeated allergen exposure and B-cell activation resulting in hyper-IgE levels in serum. The cytokine spectrum of patients with intrinsic AD is further complicated with additional cytokine axes, including Th1 (IFN- $\gamma$, CXCL9, 10, 11) and Th17 (IL-17A, CXCL8).

An attempt to stratify adult patients with $\mathrm{AD}$ by the serum biological markers has succeeded in identifying four clusters [74]. In this study, sera from 193 adult patients with moderate AD, severe AD, and healthy control subjects without AD were analyzed for serum mediators, total IgE levels, and allergen-specific IgE levels. A principal component analysis yielded four distinct clusters of patients with AD. Cluster 1 showed more severe clinical scores and more affected areas enriched with Th2 cytokines (IL-13, IL-5), as well as IL-22 and IL-33, with the highest levels of TARC, pulmonary and activation-regulated chemokines (PARC), tissue inhibitor of metalloproteinases 1 (TIMP1), and soluble CD14. Cluster 2 was characterized by a relatively low inflammatory state particularly distinctive from that of the other clusters by virtue of having low serum levels of Th2/severity-related (MDC, PARC, and TARC) and eosinophil-related (RANTES, eotaxin, and eotaxin-3) markers. Cluster 3 had more severe clinical scores with the lowest levels of IFN- $\beta$, IL-1, and epithelial cytokines, such as TSLP. Cluster 4 had milder clinical scores but the highest levels of the inflammatory Th2-related (IL-4, IL-5, and IL-13), Th1-related (IFN- $\gamma$, TNF- $\alpha$, and TNF- $\beta$ ), Th17-related (IL-17 and IL-21), and epithelial-related (IL-25, IL-33, and TSLP) cytokines 
(Figure 2). This study has been recently confirmed by the same authors in a different cohort of patients with severe AD [75].

Of note, Lauffer et al. recently identified three distinct endotypes based on serum cytokines and clinical features in children with AD that discriminate a persistent course from remission [76].

\subsection{Ethnicity and $A D$}

In relation to race, although Th2 markers (IL-13, CCL17, CCL18, and CCL22) were similar between Asian and European American patients with AD, Th1 markers were significantly lower in lesional and non-lesional tissues of Asian patients with AD [66]. Asian patients have accentuated polarity of the Th22 (IL-22 and S100A12)/Th17 (IL-17A and the related CCL20 marker) pathways, and also exhibit epidermal barrier defects despite relative maintenance of FLG and loricrin gene expression [77]. In contrast, African American patients do not exhibit FLG mutations and have distinct attenuation of Th17/Th1 axes [78,79]. Levels of IL-19, which are induced by IL-4, IL-13, and IL-17, and augment IL-17-dependent effects on keratinocytes $[80,81]$ were significantly greater in AD lesions of Asian versus EA patients (Figure 2).

\subsection{Intrinsic and Extrinsic $A D$}

The endotype pattern of AD also includes extrinsic and intrinsic AD [79,82]. Extrinsic (allergic) AD represents about $80 \%$ of adult atopic patients and is associated with a high level of serum IgE. Elderly patients with this AD endotype show frequent allergic sensitization to airborne allergens and to food allergens [83].

The intrinsic (non-allergic) AD is a less common subtype $(\approx 20 \%)$; however, it affects the elderly in an increased proportion [84]. Intrinsic AD is characterized by normal or low serum IgE levels, the absence of atopic background, and a lack of sensitization to environmental allergens. However, specific IgE against enterotoxins of S. aureus and other microbial antigens have been identified [84,85]. Intrinsic AD shows similar Th2 but higher Th17, Th1, and Th22 immune activation compared with extrinsic AD, with higher amounts of the inflammatory IL-17, CXCL8, IFN- $\gamma$, and IL-22 cytokines and related chemokines in intrinsic AD lesional skin (79) (Figure 2).

Three main phenotypes of AD have been proposed in a recent PRACTALL document: non-lesional skin, acute disease flares, and chronic remitting relapsing AD. A type 2 immune response is present in all three phenotypes, with a peak in acute disease flares. Here, the type-2 immune response is associated to a Th22- and Th17-driven inflammation present in non-lesional skin, whereas Th22- and Th1-driven responses are abundant in patients with the chronic form of AD. Epithelial dysfunction is present in non-lesional skin and in patients with chronic AD [86].

In conclusion, stratification of AD patients into distinct cytokine-based endotypes might contribute to more personalized medicine and may be important to better inform which patients are most likely to benefit from specific targeted therapies and to design disease-modifying strategies. Some biomarkers, such as CCL17 chemokine, are a consistent measurement of AD severity in multiple clinical trials. However, multiple biomarkers will probably be needed as a signature profile in AD to predict the severity, comorbidities, and treatment response.

\section{Involvement of Th1/Th2-Derived Cytokines in AD Comorbidities}

Several studies have considered AD as a systemic disorder, due to its association to a variety of conditions, known as atopic comorbidities. They include infectious, atopic, autoimmune, cardiovascular, and psychiatric disorders, which share similar immune pathogenic mechanisms with AD [87]. Frequent and severe bacterial and viral cutaneous infections are typical comorbidities of AD. S. aureus is found in up to $90 \%$ of AD lesions, while in healthy individuals, a $5-30 \%$ prevalence of colonization is reported [88]. This agent seems to be involved in the pathogenesis of AD through the induction of IL-4, IL-13, 
and IL-22 [87]. The most common viral complication in AD patients is eczema herpeticum $(\mathrm{EH})$, which tends to be more frequent in individuals with evident Th2 polarization, and consistent allergen sensitization. Th2/Th1 impaired balance leads to lower levels of antimicrobial peptides and barrier proteins. AD patients affected by EH also display low IFN- $\gamma$ levels and a down-regulation of IFN $-\gamma$ receptors, resulting in defective responses to viral multiplication [88].

The skin of individuals with AD clearly shows greater vulnerability to bacterial or fungal colonization. The predominant skin infection in AD is caused by S. aureus and the presence of specific IgE antibodies to Staphylococcus exotoxins (SE) has been demonstrated in patients with $\mathrm{AD}$ [89]. Moreover, patients with moderate to severe AD appear to have IgE to bacterial antigens more frequently than patients with mild symptoms. Furthermore, these exotoxins may play a central role not only as "allergens", but also as "superantigens", through the restricted non-MHC activation of T cells bearing the reactive TCRV $\beta$ family. $S$. aureus is in fact able to generate a series of exotoxins with super-antigenic capacity that can stimulate specific subsets of T lymphocytes. As a consequence, treatment of $S$. aureus skin infections with specific antibiotics significantly reduces the clinical severity of the disease [90].

Fungi are common and important allergens in the environment, and fungal sensitization to C. albicans, A. alternata, T., P. chrysogenum, A. fumigatus, and M. furfur is often observed in AD. IgE sensitization to Malassezia is observed in AD and not in patients with allergic rhinitis or asthma without AD. The presence in AD of specific IgE recognition of the manganese superoxide dismutase (MnSOD), a protein probably involved in IgE-mediated self-reactivity, has been demonstrated [91,92]. The hypothesis of a molecular mimicry followed by cross reactivity was raised by Schmid-Grendelmeier et al., as a result of the primary sensitization to MnSOD belonging to the Malassezia sympodialis. IgE-mediated reactivity against self-proteins with structural similarity to exogenous allergens has been hypothesized as a further potential mechanism involved in AD pathogenesis [93]. In addition to exogenous allergens, a specific IgE response can be directed against a range of human proteins located in a variety of cell and tissue types [94]. In the last two decades, five IgE-reactive auto allergens were identified using sera from severe AD patients on a human cDNA library [95-98]. A significant correlation was observed between IgE selfreactivity and $\mathrm{AD}$ severity. A reduction in the $\mathrm{IgE}$ response was observed after treatment with cyclosporine, suggesting a role for self-reactive IgE as a marker of tissue damage.

The susceptibility to skin infections is caused, at least in part, by the reduced expression of the host defense peptides (HDPs) LL-37, hBD-2, and hBD-3 observed in AD patients $[99,100]$. These peptides exhibit anti-microbial activities against skin pathogens, pro- and anti-inflammatory properties, and immunomodulatory activities [101,102]. In particular, HDPs induce cytokine and chemokine production and promote cell proliferation and migration [101,102]. HDPs also mediate the maintenance of epithelial barrier function by regulating the trans-epidermal water loss and distribution of tight junction proteins [103].

The reduced levels of HDPs may be explained by the predominance of Th2-derived cytokines, which act as strong inhibitors of LL-37, hBD-2, and hBD-3 production [102,103]. The pruritic cytokines, including IL-31 and TSLP, also have inhibitory effects on the production of these anti-microbial peptides [104,105]. FLG gene mutation in AD skin promotes perturbation of the skin barrier, but the impact of FLG on hBD levels remains controversial [99].

Atopic comorbidities, such as allergic rhinitis, asthma, and food allergy, are considered as the major criteria for AD diagnosis. They share with AD the Th2 polarization of lymphocytes, regardless of the presence or absence of IgE. Even the eyes can be frequently affected by the atopic condition, which may cause keratoconjunctivitis. Of note, the prevalence of hand eczema and allergic contact dermatitis (ACD) is increased in patients with AD [106], probably due to the action of the Th2-related (IL-4, IL-13, IL-25) and Th22-related (IL-22) cytokines, which reduce FLG levels in keratinocytes. The subsequent barrier dysfunction 
allows penetration of irritants and contact allergens. In addition, AD and ACD appear to share some immune pathways, including Th1, Th2, Th9, and Th17 [107,108].

Moreover, Koga C. et al. demonstrated a positive correlation of Th17 levels with AD clinical severity [109], whereas Nakae S. et al. reported that ACD reaction is weaker in the absence of IL-17 [110].

AD patients often use topical products, and these products may contain substances that lead to contact sensitization [111]. The last suggested mechanism to explain the association between $\mathrm{AD}$ and $\mathrm{ACD}$ is the skin bacterial colonization detected in most AD patients, which may create an inflammatory environment favoring contact sensitization [112]. The risk of irritative contact dermatitis is approximately three-fold in AD patients due to the impaired barrier function. The altered function of FLG is a common pathogenic mechanism in AD, and this can also be observed in ichthyosis vulgaris and keratosis pilaris. Indeed, an association of these diseases with AD has been reported [106].

Furthermore, the increased Th17 activity could, at least in part, explain the association between $\mathrm{AD}$ and some autoimmune diseases (i.e., inflammatory bowel diseases, rheumatoid arthritis, and lupus erythematosus) [113]. The correlation between AD and autoimmune diseases, including alopecia areata and vitiligo, could be due to the presence of some specific susceptibility genes shared among them.

In addition, AD patients more frequently suffer from depression and suicidality [114]. According to some studies, they also are at an increased risk of developing attention deficit hyperactivity disorder during childhood [115]. This could be explained by the relevant impact of AD on the patients' quality of life [116], and more specifically by the prevalence and intensity of itching often associated with sleep disturbances, which may interfere with brain development in children [117], but also by early exposure of the central nervous system to inflammatory Th2 cytokines and systemic corticosteroids in pediatric age [118].

An increased risk of non-Hodgkin lymphomas has been observed in AD patients [119], possibly due to chronic inflammation and Th2 polarization able to reduce Th1 anti-neoplastic activity. An increased cardiovascular risk has even been found with a higher incidence of myocardial infarction and congestive heart disease; however, this seems to be attributable to poor health behaviors and more frequent cardiovascular risk factors rather than the atopic condition itself [120].

\section{Cytokines and Their Intracellular Effectors as Therapeutic Targets in AD}

Therapeutic strategies for AD vary according to several factors, including the severity of disease, extent and location of the affected body area, age, comorbidities, and quality of life of the patient. In recent years, the therapeutic choice for moderate to severe AD has been widened by the remarkable development of new target therapies, which not only allow more personalized treatment, but also bypass the possible toxicities of conventional therapies [121,122]. Some of these drugs are still in the trial phase, but others are already approved by the FDA and EMA (Table 2).

Dupilumab is a human monoclonal antibody directed against subunit $\alpha$ of the IL-4 receptor, which is also part of the IL-13 receptor. Through inhibition of the signaling of these two cytokines, dupilumab significantly improves Investigator's Global Assessment (IGA), EASI (Eczema Area and Severity Index), and symptoms [123]. The most frequently reported adverse event in clinical trials in AD patients was conjunctivitis (8-22\% of cases), but, in patients without AD and treated with dupilumab, no conjunctivitis occurred, making this a disease-specific adverse effect [124]. The safety and efficacy of dupilumab allowed its approval in 2017 in the U.S. and in Europe for moderate-severe AD in adults [124] and its recent approval even for adolescents from 12 years of age [125]. To date, it is not clear how long the therapy should be continued or whether or not it can be alternated with other therapeutic approaches. 
Table 2. Therapeutic approaches in AD: molecular and cellular targets of biologics and small molecules.

\begin{tabular}{|c|c|c|c|}
\hline Biologics & Molecular Target & Intracellular Mediators & Cellular Target \\
\hline Dupilumab & $\begin{array}{l}\text { IL-4/IL-13 receptor } \\
\text { ( } \alpha \text { subunit) }\end{array}$ & JAK1/JAK3 & $\begin{array}{l}\text { Keratinocytes, B cells, cutaneous peripheral } \\
\text { sensory neurons }\end{array}$ \\
\hline Tralokinumab & IL-13 receptor ( $\alpha 1$ and $\alpha 2$ chains) & JAK1/JAK2 & $\begin{array}{c}\text { Keratinocytes, B cells, cutaneous peripheral } \\
\text { sensory neurons }\end{array}$ \\
\hline Lebrikizumab & IL-13 receptor ( $\alpha 1$ chain) & JAK1/JAK2 & Keratinocytes, B cells \\
\hline Nemolizumab & IL-31 receptor ( $\alpha$ subunit) & JAK1/JAK2 & $\begin{array}{l}\text { Immune cells, keratinocytes and cutaneous } \\
\text { peripheral sensory neurons }\end{array}$ \\
\hline Etokimab & IL-33 & Myd88/IRAK-1/IRAK-4 & Keratinocytes, cutaneous peripheral sensory \\
\hline GBR830 and KHK4083 & OX40 & TRAF-5, $-6,-2$ & Th2 cells \\
\hline Tezepelumab & TSLP & JAK1, JAK2 & $\begin{array}{c}\text { DC, ILC2, MC, sensory neurons, } \\
\text { Ag-specific Th2 cells }\end{array}$ \\
\hline Fezakinumb & IL-22 & TYK2, JAK1 & Keratinocytes, dermal endothelial cells \\
\hline Small Molecules & Intracellular Target & Cytokine Target & Clinical Trial Stage \\
\hline Tofacitinib & JAK1/JAK3 & IL-4, partly IL-13, TSLP, IL-22, IL-31 & $\begin{array}{l}\text { Phase II completed (Topical) } \\
\text { (NTC\#02001181) }\end{array}$ \\
\hline Baricitinib & JAK1/JAK2 & IL-13, TSLP, partly IL-4, IL-31, IL-22 & $\begin{array}{l}\text { Phase III completed } \\
\text { (NTC\#03559270) }\end{array}$ \\
\hline Peficitinib & Pan-JAK & IL-4, IL-13, IL-31, TSLP, IL-22 & $\begin{array}{l}\text { Phase II ongoing } \\
\text { (NTC\#04218877) }\end{array}$ \\
\hline Delgocitinib & Pan-JAK & IL-4, IL-13, IL-31, TSLP, IL-22 & $\begin{array}{l}\text { Phase II ongoing } \\
\text { (NTC\#03725722) }\end{array}$ \\
\hline Upadacitinib & JAK1 & Partly IL-4, IL-13, TSLP & $\begin{array}{l}\text { Phase III ongoing } \\
\text { (NTC\#03569293) }\end{array}$ \\
\hline Abrocitinib & JAK1 & Partly IL-4, IL-13, TSLP & $\begin{array}{l}\text { Phase III completed } \\
\text { (NTC\#04564755) }\end{array}$ \\
\hline
\end{tabular}

The IL-13 signaling pathway is also blocked by other monoclonal antibodies currently being tested, in particular tralokinumab and lebrikizumab, which showed excellent results in clinical trials. Specifically, tralokinumab blocks the binding of IL-13 to both receptor chains, whereas lebrikizumab only blocks binding to the $\alpha 1$ chain, conversely allowing binding to the $\alpha 2$ chain, which plays a useful regulatory role [123] (Table 2).

Even the IL-31 pathway is currently under investigation. IL-31R seems to play a key role in the modulation of pruritus in AD patients. Indeed, it is expressed not only by immune cells, but also by keratinocytes and cutaneous peripheral sensory neurons. Nemolizumab is a humanized antibody targeting $\alpha$ subunit of IL-31R that has shown significant improvements in AD severity scores with few adverse effects (i.e., nasopharyngitis and upper respiratory infections) [123]. There is no approved indication for this drug yet [124]. Therapeutic strategies to inhibit IL-33 activity are under investigation as treatments for moderate to severe AD.

An anti-IL-33 monoclonal antibody, etokimab, was used in recent phase 2 clinical trials, showing an important reduction in skin inflammatory cascades [126].

Other signaling pathways under investigation are TSLP, OX40, and IL-22. TSLP activates dendritic cells, inducing Th2 polarization; it is the target of the human monoclonal antibody tezepelumab, which shows positive results in trials. OX40 is a costimulatory molecule of the TNF receptor, expressed mainly on T lymphocytes. Since the OX40 ligand is overexpressed on dendritic cells in AD patients, blocking this pathway is the new target of monoclonal antibodies GBR830 and KHK4083. IL-22 is a major contributor to cytokine-mediated dysfunction in keratinocytes and endothelial cells in AD. Fezakinumb, an IL-22 antagonist, has been developed, demonstrating good outcomes in phase 2 studies [123] (Table 2).

In addition to biological drugs, small-molecule inhibitors are a useful pharmacological class in development for the treatment of AD. Some of these drugs directly block JAK/STAT proteins, which are intracellularly activated by cytokine receptors and shared by groups of cytokine signals, in particular those related to IL-4, IL-5, IL-13, IL-31 and TSLP. For example, JAK1 is shared by signaling pathways induced by IL-4, TLSP, IL-13, IL-22 and IFN- $\gamma$, whereas TYK2 is common to IL-13 and IL-22 signaling. Based on these molecular features, most of JAK inhibitors synergistically act as inhibitors of both the inflammatory responses and pruritus [127]. 
Tofacitinib, a JAK1/JAK3 inhibitor, has been approved for RA and psoriatic arthritis, whereas baricitinib is a JAK1/JAK2 inhibitor approved for RA and the treatment of AD in Europe. Recently, baricitinib received emergency approval, in combination with the antiviral remdesivir, for the treatment of COVID-19 [128]. Peficitinib is a pan-JAK inhibitor approved in Japan for the treatment of RA, whereas delgocitinib (JTE-052) is a topical JAK inhibitor approved in Japan for AD [129]. Finally, upadacitinib has a degree of selectivity for JAK1 over JAK2 and is approved for the treatment of RA and AD in Europe [130].

The systemic JAK inhibitors (baricitinib, upadacitinib, and abrocitinib) show a rapid efficacy with rapid improvement of pruritus and a good tolerability in AD patients. However, topical application of JAK inhibitors is expected to play an important role in new therapeutic concepts for AD patient management, particularly for children (Table 2).

\section{Conclusions}

In summary, the complex clinical heterogeneity of AD needs newer and more effective treatments that are able to control the disease and improve the quality of life of patients. To date, biologics have showed long-term control of AD symptoms, whereas JAK inhibitors provide rapid relief in pruritus and inflammation. However, although well-tolerated, benefit-risk ratio of JAKs inhibitors remains a key issue for pharmacovigilance.

Some of these drugs even have the potential to modify the disease and could impact the atopic march and other comorbidities, if applied in the early phase of AD. Of note, specific cytokine profiles and barrier abnormalities characterize different $\mathrm{AD}$ groups and should be carefully considered when future therapeutic agents are being developed or tested for younger patients with AD. Therefore, accompanied by a deep characterization of different phenotype and endotype subsets, the application of precision medicine could provide new prospects for the optimal treatment of AD.

Funding: This work was supported by a grant founded by Italian Ministry of Health (Ricerca Corrente RC-2021).

Institutional Review Board Statement: Not applicable.

Informed Consent Statement: Not applicable.

Data Availability Statement: Not applicable.

Conflicts of Interest: The authors declare no conflict of interest.

\section{References}

1. Bieber, T. Atopic dermatitis: An expanding therapeutic pipeline for a complex disease. Nat. Rev. Drug Discov. 2022, 21, 21-40. [CrossRef] [PubMed]

2. Barbarot, S.; Auziere, S.; Gadkari, A.; Girolomoni, G.; Puig, L.; Simpson, E.L.; Margolis, D.J.; de Bruin-Weller, M.; Eckert, L. Epidemiology of atopic dermatitis in adults: Results from an international survey. Allergy 2018, 73, 1284-1293. [CrossRef] [PubMed]

3. Laughter, M.R.; Maymone, M.B.C.; Mashayekhi, S.; Arents, B.W.M.; Karimkhani, C.; Langan, S.M.; Dellavalle, R.P.; Flohr, C. The global burden of atopic dermatitis: Lessons from the Global Burden of Disease Study 1990-2017. Br. J. Dermatol. 2021, 184, 304-309. [CrossRef] [PubMed]

4. Langan, S.M.; Irvine, A.D.; Weidinger, S. Atopic dermatitis. Lancet 2020, 396, 345-360. [CrossRef]

5. Kim, J.; Kim, B.E.; Leung, D.Y.M. Pathophysiology of atopic dermatitis: Clinical implications. Allergy Asthma Proc. 2019, 40, 84-92. [CrossRef]

6. Paller, A.S.; Spergel, J.M.; Mina-Osorio, P.; Irvine, A.D. The atopic march and atopic multi-morbidity: Many trajectories, many pathways. J. Allergy Clin. Immunol. 2019, 143, 46-55. [CrossRef]

7. Girolomoni, G.; Abeni, D.; Masini, C.; Sera, F.; Ayala, F.; Belloni-Fortina, A.; Bonifazi, E.; Fabbri, P.; Gelmetti, C.; Monfrecola, G.; et al. The epidemiology of atopic dermatitis in Italian schoolchildren. Allergy 2003, 58, 420-425. [CrossRef]

8. Weidinger, S.; Novak, N. Atopic dermatitis. Lancet 2016, 387, 1109-1122. [CrossRef]

9. Eyerich, S.; Onken, A.T.; Weidinger, S.; Franke, A.; Nasorri, F.; Pennino, D.; Grosber, M.; Pfab, F.; Schmidt-Weber, C.B.; Mempel, M.; et al. Mutual antagonism of T cells causing psoriasis and atopic eczema. N. Engl. J. Med. 2011, 365, 231-238. [CrossRef]

10. Furue, M. Regulation of Filaggrin, Loricrin, and Involucrin by IL-4, IL-13, IL-17A, IL-22, AHR, and NRF2: Pathogenic Implications in Atopic Dermatitis. Int. J. Mol. Sci. 2020, 21, 5382. [CrossRef] 
11. Saunders, S.P.; Moran, T.; Floudas, A.; Wurlod, F.; Kaszlikowska, A.; Salimi, M.; Quinn, E.M.; Oliphant, C.J.; Núñez, G.; McManus, R.; et al. Spontaneous atopic dermatitis is mediated by innate immunity, with the secondary lung inflammation of the atopic march requiring adaptive immunity. J. Allergy Clin. Immunol. 2016, 137, 482-491. [CrossRef] [PubMed]

12. Chieosilapatham, P.; Kiatsurayanon, C.; Umehara, Y.; Trujillo-Paez, J.V.; Peng, G.; Yue, H.; Nguyen, L.T.H.; Niyonsaba, F. Keratinocytes: Innate immune cells in atopic dermatitis. Clin. Exp. Immunol. 2021, 204, 296-309. [CrossRef] [PubMed]

13. Han, H.; Roan, F.; Ziegler, S.F. The atopic march: Current insights into skin barrier dysfunction and epithelial cell-derived cytokines. Immunol. Rev. 2017, 278, 116-130. [CrossRef] [PubMed]

14. Palmer, C.N.; Irvine, A.D.; Terron-Kwiatkowski, A.; Zhao, Y.; Liao, H.; Lee, S.P.; Goudie, D.R.; Sandilands, A.; Campbell, L.E.; Smith, F.J.; et al. Common loss-of-function variants of the epidermal barrier protein filaggrin are a major predisposing factor for atopic dermatitis. Nat. Genet. 2006, 38, 441-446. [CrossRef] [PubMed]

15. Hönzke, S.; Wallmeyer, L.; Ostrowski, A.; Radbruch, M.; Mundhenk, L.; Schäfer-Korting, M.; Hedtrich, S. Influence of Th2 Cytokines on the Cornified Envelope, Tight Junction Proteins, and B-Defensins in Filaggrin-Deficient Skin Equivalents. J. Investig. Dermatol. 2016, 136, 631-639. [CrossRef] [PubMed]

16. Kezic, S.; O’Regan, G.M.; Lutter, R.; Jakasa, I.; Koster, E.S.; Saunders, S.; Caspers, P.; Kemperman, P.M.; Puppels, G.J.; Sandilands, A.; et al. Filaggrin loss-of-function mutations are associated with enhanced expression of IL-1 cytokines in the stratum corneum of patients with atopic dermatitis and in a murine model of filaggrin deficiency. J. Allergy Clin. Immunol. 2012, 129, 1031-1039.e1. [CrossRef]

17. Archer, N.K.; Jo, J.H.; Lee, S.K.; Kim, D.; Smith, B.; Ortines, R.V.; Wang, Y.; Marchitto, M.C.; Ravipati, A.; Cai, S.S.; et al. Injury, dysbiosis, and filaggrin deficiency drive skin inflammation through keratinocyte IL-1 $\alpha$ release. J. Allergy Clin. Immunol. 2019, 143, 1426-1443.e6. [CrossRef]

18. Savinko, T.; Matikainen, S.; Saarialho-Kere, U.; Lehto, M.; Wang, G.; Lehtimäki, S.; Karisola, P.; Reunala, T.; Wolff, H.; Lauerma, A.; et al. IL-33 and ST2 in atopic dermatitis: Expression profiles and modulation by triggering factors. J. Investig. Dermatol. 2012, 132, 1392-1400. [CrossRef]

19. Imai, Y. Interleukin-33 in atopic dermatitis. J. Dermatol. Sci. 2019, 96, 2-7. [CrossRef]

20. Imai, Y.; Yasuda, K.; Sakaguchi, Y.; Haneda, T.; Mizutani, H.; Yoshimoto, T.; Nakanishi, K.; Yamanishi, K. Skin-specific expression of IL-33 activates group 2 innate lymphoid cells and elicits atopic dermatitis-like inflammation in mice. Proc. Natl. Acad. Sci. USA 2013, 110, 13921-13926. [CrossRef]

21. Roan, F.; Obata-Ninomiya, K.; Ziegler, S.F. Epithelial cell-derived cytokines: More than just signaling the alarm. J. Clin. Investig. 2019, 129, 1441-1451. [CrossRef]

22. Garcovich, S.; Maurelli, M.; Gisondi, P.; Peris, K.; Yosipovitch, G.; Girolomoni, G. Pruritus as a Distinctive Feature of Type 2 Inflammation. Vaccines 2021, 9, 303. [CrossRef] [PubMed]

23. Ryu, W.I.; Lee, H.; Bae, H.C.; Ryu, H.J.; Son, S.W. IL-33 down-regulates filaggrin expression by inducing STAT3 and ERK phosphorylation in human keratinocytes. J. Dermatol. Sci. 2016, 82, 131-134. [CrossRef] [PubMed]

24. Topal, F.A.; Zuberbier, T.; Makris, M.P.; Hofmann, M. The role of IL-17, IL-23 and IL-31, IL-33 in allergic skin diseases. Curr. Opin. Allergy Clin. Immunol. 2020, 20, 367-373. [CrossRef]

25. Chieosilapatham, P.; Ikeda, S.; Ogawa, H.; Niyonsaba, F. Tissue-specific Regulation of Innate Immune Responses by Human Cathelicidin LL-37. Curr. Pharm. Des. 2018, 24, 1079-1091. [CrossRef]

26. Coates, M.; Blanchard, S.; MacLeod, A.S. Innate antimicrobial immunity in the skin: A protective barrier against bacteria, viruses, and fungi. PLoS Pathog. 2018, 14, e1007353. [CrossRef]

27. Miller, L.S. Toll-like receptors in skin. Adv. Dermatol. 2008, 24, 71-87. [CrossRef]

28. Di Cesare, A.; Di Meglio, P.; Nestle, F.O. A role for Th17 cells in the immunopathogenesis of atopic dermatitis? J. Investig. Dermatol. 2008, 128, 2569-2571. [CrossRef]

29. Liu, H.; Archer, N.K.; Dillen, C.A.; Wang, Y.; Ashbaugh, A.G.; Ortines, R.V.; Kao, T.; Lee, S.K.; Cai, S.S.; Miller, R.J.; et al Staphylococcus aureus Epicutaneous Exposure Drives Skin Inflammation via IL-36-Mediated T Cell Responses. Cell Host Microbe 2017, 22, 653-666.e5. [CrossRef]

30. Wang, Y.H.; Liu, Y.J. Thymic stromal lymphopoietin, OX40-ligand, and interleukin-25 in allergic responses. Clin. Exp. Allergy 2009, 39, 798-806. [CrossRef]

31. Lee, K.H.; Cho, K.; Kim, J.Y.; Kim, J.Y.; Baek, J.H.; Woo, S.Y.; Kim, J.W. Filaggrin knockdown and Toll-like receptor 3 (TLR3) stimulation enhanced the production of thymic stromal lymphopoietin (TSLP) from epidermal layers. Exp. Dermatol. 2011, 20, 149-151. [CrossRef] [PubMed]

32. Cianferoni, A.; Spergel, J. The importance of TSLP in allergic disease and its role as a potential therapeutic target. Expert Rev. Clin. Immunol. 2014, 10, 1463-1474. [CrossRef] [PubMed]

33. Xie, Y.; Takai, T.; Chen, X.; Okumura, K.; Ogawa, H. Long TSLP transcript expression and release of TSLP induced by TLR ligands and cytokines in human keratinocytes. J. Dermatol. Sci. 2012, 66, 233-237. [CrossRef] [PubMed]

34. Chieosilapatham, P.; Ogawa, H.; Niyonsaba, F. Current insights into the role of human $\beta$-defensins in atopic dermatitis. Clin. Exp. Immunol. 2017, 190, 155-166. [CrossRef]

35. Wilson, S.R.; Thé, L.; Batia, L.M.; Beattie, K.; Katibah, G.E.; McClain, S.P.; Pellegrino, M.; Estandian, D.M.; Bautista, D.M. The epithelial cell-derived atopic dermatitis cytokine TSLP activates neurons to induce itch. Cell 2013, 155, 285-295. [CrossRef] 
36. Borowczyk, J.; Shutova, M.; Brembilla, N.C.; Boehncke, W.H. IL-25 (IL-17E) in epithelial immunology and pathophysiology. J. Allergy Clin. Immunol. 2021, 148, 140-152. [CrossRef]

37. Liu, Y.; Shao, Z.; Shangguan, G.; Bie, Q.; Zhang, B. Biological Properties and the Role of IL-25 in Disease Pathogenesis. J. Immunol. Res. 2018, 23, 6519465. [CrossRef]

38. Hvid, M.; Vestergaard, C.; Kemp, K.; Christensen, G.B.; Deleuran, B.; Deleuran, M. IL-25 in atopic dermatitis: A possible link between inflammation and skin barrier dysfunction? J. Investig. Dermatol. 2011, 131, 150-157. [CrossRef]

39. Dubin, C.; Del Duca, E.; Guttman-Yassky, E. The IL-4, IL-13 and IL-31 pathways in atopic dermatitis. Expert Rev. Clin. Immunol. 2021, 17, 835-852. [CrossRef]

40. Oetjen, L.K.; Mack, M.R.; Feng, J.; Whelan, T.M.; Niu, H.; Guo, C.J.; Chen, S.; Trier, A.M.; Xu, A.Z.; Tripathi, S.V. Sensory Neurons Co-opt Classical Immune Signaling Pathways to Mediate Chronic Itch. Cell 2017, 171, 217-228.e13. [CrossRef]

41. Namita, A.; Gandhi, A.; Bennett, B.L.; Graham, N.M.H.; Pirozzi, G.; Stahl, N.; Yancopoulos, G.D. Targeting key proximal drivers of type 2 inflammation in disease. Nat. Rev. Drug Discov. 2016, 15, 35-50. [CrossRef]

42. Calderón, M.A.; Devalia, J.L.; Prior, A.J.; Sapsford, R.J.; Davies, R.J. A comparison of cytokine release from epithelial cells cultured from nasal biopsy specimens of atopic patients with and without rhinitis and nonatopic subjects without rhinitis. J. Allergy Clin. Immunol. 1997, 99, 65-76. [CrossRef]

43. Weidinger, S.; Beck, L.A.; Bieber, T.; Kabashima, K.; Irvine, A.D. Atopic dermatitis. Nat. Rev. Dis. Primers 2018, 4, 1. [CrossRef] [PubMed]

44. Jin, M.; Yoon, J. From Bench to Clinic: The Potential of Therapeutic Targeting of the IL-22 Signaling Pathway in Atopic Dermatitis. Immune Netw. 2018, 18, e42. [CrossRef]

45. Yoon, J.; Leyva-Castillo, J.M.; Wang, G.; Galand, C.; Oyoshi, M.K.; Kumar, L.; Hoff, S.; He, R.; Chervonsky, A.; Oppenheim, J.J.; et al. IL-23 induced in keratinocytes by endogenous TLR4 ligands polarizes dendritic cells to drive IL22 responses to skin immunization. J. Exp. Med. 2016, 213, 2147-2166. [CrossRef]

46. Gittler, J.K.; Shemer, A.; Suárez-Fariñas, M.; Fuentes-Duculan, J.; Gulewicz, K.J.; Wang, C.Q.F.; Mitsui, H.; Cardinale, I.; de Guzman Strong, C.; Krueger, J.G.; et al. Progressive activation of T(H)2/T(H)22 cytokines and selective epidermal proteins characterizes acute and chronic atopic dermatitis. J. Allergy Clin. Immunol. 2012, 130, 1344-1354. [CrossRef]

47. Tsoi, L.C.; Rodriguez, E.; Stölzl, D.; Wehkamp, U.; Sun, J.; Gerdes, S.; Sarkar, M.K.; Hübenthal, M.; Zeng, C.; Uppala, R.; et al. Progression of acute-to-chronic atopic dermatitis is associated with quantitative rather than qualitative changes in cytokine responses. J. Allergy Clin. Immunol. 2020, 145, 1406-1415. [CrossRef]

48. Albanesi, A.; Scarponi, C.; Sebastiani, S.; Cavani, A.; Federici, M.; De Pità, O.; Puddu, P.; Girolomoni, G. IL-4 enhances keratinocyte expression of CXCR3 agonistic chemokines. J. Immunol. 2000, 165, 1395-1402. [CrossRef]

49. Mercurio, L.; Failla, C.M.; Capriotti, L.; Scarponi, C.; Facchiano, F.; Morelli, M.; Rossi, S.; Pagnanelli, G.; Albanesi, C.; Cavani, A.; et al. Interleukin (IL)-17/IL-36 axis participates to the crosstalk between endothelial cells and keratinocytes during inflammatory skin responses. PLoS ONE 2020, 15, e0222969. [CrossRef]

50. Mercurio, L.; Morelli, M.; Scarponi, C.; Eisenmesser, E.Z.; Doti, N.; Pagnanelli, G.; Gubinelli, E.; Mazzanti, C.; Cavani, A.; Ruvo, M.; et al. IL-38 has an anti-inflammatory action in psoriasis and its expression correlates with disease severity and therapeutic response to anti-IL-17A treatment. Cell Death Dis. 2018, 9, 1104. [CrossRef]

51. Madonna, S.; Girolomoni, G.; Dinarello, C.A.; Albanesi, C. The Significance of IL-36 Hyperactivation and IL-36R Targeting in Psoriasis. Int. J. Mol. Sci. 2019, 20, 3318. [CrossRef] [PubMed]

52. Foster, A.M.; Baliwag, J.; Chen, C.S.; Guzman, A.M.; Stoll, S.W.; Gudjonsson, J.E.; Ward, N.L.; Johnston, A. IL-36 promotes myeloid cell infiltration, activation, and inflammatory activity in skin. J. Immunol. 2014, 192, 6053-6061. [CrossRef]

53. Shao, S.; Tsoi, L.C.; Swindell, W.R.; Chen, J.; Uppala, R.; Billi, A.C.; Xing, X.; Zeng, C.; Sarkar, M.K.; Wasikowski, R. IRAK2 Has a Critical Role in Promoting Feed-Forward Amplification of Epidermal Inflammatory Responses. J. Investig. Dermatol. 2021, 141, 2436-2448. [CrossRef] [PubMed]

54. Eyerich, S.; Metz, M.; Bossios, A.; Eyerich, K. New biological treatments for asthma and skin allergies. Allergy 2020, 75, 546-560. [CrossRef]

55. Erickson, S.; Heul, A.V.; Kim, B.S. New and emerging treatments for inflammatory itch. Ann. Allergy Asthma Immunol. 2021, 126, 13-20. [CrossRef]

56. Datsi, A.; Steinhoff, M.; Ahmad, F.; Alam, M.; Buddenkotte, J. New and emerging treatments for inflammatory itch. Allergy 2021, 76, 2982-2997. [CrossRef]

57. Sonkoly, E.; Muller, A.; Lauerma, A.I.; Pivarcsi, A.; Soto, H.; Kemeny, L.; Alenius, H.; Dieu-Nosjean, M.C.; Meller, S.; Rieker, J.; et al. IL-31: A new link between T cells and pruritus in atopic skin inflammation. J. Allergy Clin. Immunol. 2006, 117, 411-417. [CrossRef] [PubMed]

58. Nobbe, S.; Dziunycz, P.; Mühleisen, B.; Bilsborough, J.; Dillon, S.R.; French, L.E.; Hofbauer, F.F.L. IL-31 expression by inflammatory cells is preferentially elevated in atopic dermatitis. Acta Derm.-Venereol. 2012, 92, 24-28. [CrossRef] [PubMed]

59. Szegedi, K.; Kremer, A.E.; Kezic, S.; Teunissen, M.B.M.; Bos, J.D.; Luiten, R.M.; Res, P.C.; Middelkamp-Hup, M.S. Increased frequencies of IL-31-producing T cells are found in chronic atopic dermatitis skin. Exp. Dermatol. 2012, 21, 431-436. [CrossRef]

60. Ezzat, M.H.M.; Hasan, Z.E.; Shaheen, K.Y.A. Serum measurement of interleukin-31 (IL-31) in paediatric atopic dermatitis: Elevated levels correlate with severity scoring. J. Eur. Acad. Dermatol. Venereol. 2011, 25, 334-339. [CrossRef] 
61. Raap, U.; Weißmantel, S.; Gehring, M.; Eisenberg, A.M.; Kapp, A.; Fölster-Holst, R. IL-31 significantly correlates with disease activity and Th2 cytokine levels in children with atopic dermatitiS. Pediatr. Allergy Immunol. 2012, 23, 285-288. [CrossRef] [PubMed]

62. Kato, A.; Fujii, E.; Watanabe, T.; Takashima, Y.; Matsushita, H.; Furuhashi, T.; Morita, A. Distribution of IL-31 and its receptor expressing cells in skin of atopic dermatitis. J. Dermatol. Sci. 2014, 74, 229-235. [CrossRef]

63. Cornelissen, C.; Marquardt, Y.; Czaja, K.; Wenzel, J.; Frank, J.; Lüscher-Firzlaff, J.; Lüscher, B.; Baron, J.M. IL-31 regulates differentiation and filaggrin expression in human organotypic skin models. J. Allergy Clin. Immunol. 2012, 129, 426-433.e8. [CrossRef] [PubMed]

64. Yosipovitch, G.; Berger, T.; Fassett, M.S. Neuroimmune interactions in chronic itch of atopic dermatitis. J. Eur. Acad. Dermatol. Venereol. 2020, 34, 239-250. [CrossRef] [PubMed]

65. Fujii, M. Current Understanding of Pathophysiological Mechanisms of Atopic Dermatitis: Interactions among Skin Barrier Dysfunction, Immune Abnormalities and Pruritus. Biol. Pharm. Bull. 2020, 43, 12-19. [CrossRef]

66. Czarnowicki, T.; He, H.; Krueger, J.G.; Guttman-Yassky, E. Atopic dermatitis endotypes and implications for targeted therapeutics. J. Allergy Clin. Immunol. 2019, 143, 1-11. [CrossRef]

67. Brunner, P.M.; Israel, A.; Zhang, N.; Leonard, A.; Wen, U.C.; Huynh, T.; Tran, G.; Lyon, S.; Rodriguez, G.; Immaneni, S. Early-onset pediatric atopic dermatitis is characterized by $\mathrm{T}_{\mathrm{H}} 2 / \mathrm{T}_{\mathrm{H}} 17 / \mathrm{T}_{\mathrm{H}} 22$-centered inflammation and lipid alterations. J. Allergy Clin. Immunol. 2018, 141, 2094-2106. [CrossRef]

68. Nomura, T.; Wu, J.; Kabashima, K.; Guttman-Yassky, E. Endophenotypic Variations of Atopic Dermatitis by Age, Race, and Ethnicity. J. Allergy Clin. Immunol. Pract. 2020, 8, 1840-1852. [CrossRef]

69. Trichot, C.; Faucheux, L.; Karpf, L.; Grandclaudon, M.; Pattarini, L.; Bagot, M.; Mahévas, T.; Jachiet, M.; Saussine, A.; Bouaziz, J.D.; et al. Th cell diversity and response to dupilumab in patients with atopic dermatitis. J. Allergy Clin. Immunol. 2021, 147, 756-759. [CrossRef]

70. Renert-Yuval, Y.; Thyssen, J.P.; Bissonnette, R.; Bieber, T.; Kabashima, K.; Hijnen, D.; Guttman-Yassky, E. Biomarkers in atopic dermatitis-A review on behalf of the International Eczema Council. J. Allergy Clin. Immunol. 2021, 147, 1174-1190.e1. [CrossRef]

71. Esaki, H.; Brunner, P.M.; Renert-Yuval, Y.; Czarnowicki, T.; Huynh, T.; Tran, G.; Lyon, S.; Rodriguez, G.; Immaneni, S.; Johnson, D.B. Early-onset pediatric atopic dermatitis is $\mathrm{T}_{\mathrm{H}} 2$ but also $\mathrm{T}_{\mathrm{H}} 17$ polarized in skin. J. Allergy Clin. Immunol. 2016, 138, 1639-1651. [CrossRef] [PubMed]

72. Renert-Yuval, Y.; Del Duca, E.; Pavel, A.B.; Fang, M.; Lefferdink, R.; Wu, J.; Diaz, A.; Estrada, Y.D.; Canter, T.; Zhang, N. The molecular features of normal and atopic dermatitis skin in infants, children, adolescents, and adult. J. Allergy Clin. Immunol. 2021, 148, 148-163. [CrossRef]

73. Pavel, A.B.; Renert-Yuval, J.; Wu, J.; Del Duca, E.; Diaz, A.; Lefferdink, R.; Fang, M.M.; Canter, T.; Rangel, S.M.; Zhang, N. Tape strips from early-onset pediatric atopic dermatitis highlight disease abnormalities in nonlesional skin. Allergy 2021, 76, 314-325. [CrossRef] [PubMed]

74. Thijs, J.L.; Strickland, I.; Bruijnzeel-Koomen, C.A.F.M.; Nierkens, S.; Giovannone, B.; Csomor, E.; Sellman, B.R.; Mustelin, T.; Sleeman, M.A.; de Bruin-Weller, M.S.; et al. Moving toward endotypes in atopic dermatitis: Identification of patient clusters based on serum biomarker analysis. J. Allergy Clin. Immunol. 2017, 140, 730-737. [CrossRef] [PubMed]

75. Bakker, D.S.; Nierkens, S.; Knol, E.F.; Giovannone, B.; Delemarre, E.M.; van der Schaft, J.; van Wijk, F.; de Bruin-Weller, M.S.; Drylewicz, J.; Thijs, J.L. Confirmation of multiple endotypes in atopic dermatitis based on serum biomarkers. J. Allergy Clin. Immunol. 2021, 147, 189-198. [CrossRef] [PubMed]

76. Lauffer, F.; Baghin, V.; Standl, M.; Stark, S.P.; Jargosch, M.; Wehrle, J.; Thomas, J.; Schmidt-Weber, C.B.; Biedermann, T.; Eyerich, S.; et al. Predicting persistence of atopic dermatitis in children using clinical attributes and serum proteins. Allergy 2021, 76, 1158-1172. [CrossRef] [PubMed]

77. Noda, S.; Suárez-Fariñas, M.; Ungar, B.; Kim, S.J.; de Guzman Strong, C.; Xu, H.; Peng, X.; Estrada, Y.D.; Nakajima, S.; Honda, T.; et al. The Asian atopic dermatitis phenotype combines features of atopic dermatitis and psoriasis with increased TH17 polarization. J. Allergy Clin. Immunol. 2015, 136, 1254-1264. [CrossRef]

78. Czarnowicki, T.; Esaki, H.; Gonzalez, J.; Malajian, D.; Shemer, A.; Noda, S.; Talasila, S.; Berry, A.; Gray, J.; Becker, L.; et al. Early pediatric atopic dermatitis shows only a cutaneous lymphocyte antigen (CLA)(+) TH2/TH1 cell imbalance, whereas adults acquire CLA(+) TH22/TC22 cell subsets. J. Allergy Clin. Immunol. 2015, 136, 941-951.e3. [CrossRef]

79. Suárez-Fariñas, M.; Dhingra, N.; Gittler, J.; Shemer, A.; Cardinale, I.; de Guzman Strong, C.; Krueger, J.G.; Guttman-Yassky, E. Intrinsic atopic dermatitis shows similar TH2 and higher TH17 immune activation compared with extrinsic atopic dermatitis. $J$. Allergy Clin. Immunol. 2013, 132, 361-370. [CrossRef]

80. Witte, E.; Kokolakis, G.; Witte, K.; Philipp, S.; Doecke, W.D.; Babel, N.; Wittig, B.M.; Warszawska, K.; Kurek, A.; Erdmann-Keding, M.; et al IL-19 is a component of the pathogenetic IL-23/IL-17 cascade in psoriasis. J Investig. Dermatol. 2014, 134, 2757-2767. [CrossRef]

81. Huang, F.; Wachi, S.; Thai, P.; Loukoianov, A.; Tan, K.H.; Forteza, R.M.; Wu, R. Potentiation of IL-19 expression in airway epithelia by IL-17A and IL-4/IL-13: Important implications in asthma. J. Allergy Clin. Immunol. 2008, 121, 1415-1421. [CrossRef]

82. Tokura, Y. Extrinsic and intrinsic types of atopic dermatitis. J. Dermatol Sci. 2010, 58, 1-7. [CrossRef] [PubMed]

83. Tanei, R. Clinical Characteristics, Treatments, and Prognosis of Atopic Eczema in the Elderly. J. Clin. Med. 2015, 18, 979-997. [CrossRef] [PubMed] 
84. Zhou, L.; Leonard, A.; Pavel, A.B.; Malik, K.; Raja, A.; Glickman, J.; Estrada, Y.D.; Peng, X.; Del Duca, E.; Sanz-Cabanillas, J.; et al. Age-specific changes in the molecular phenotype of patients with moderate-to-severe atopic dermatitis. J. Allergy Clin. Immunol. 2019, 144, 144-156. [CrossRef] [PubMed]

85. Bozek, A.; Fisher, A.; Filipowska, B.; Mazur, B.; Jarzab, J. Clinical features and immunological markers of atopic dermatitis in elderly patients. Int. Arch. Allergy Immunol. 2012, 157, 372-378. [CrossRef]

86. Muraro, A.; Lemanske, R.F., Jr.; Hellings, P.W.; Akdis, C.A.; Bieber, T.; Casale, T.B.; Jutel, M.; Ong, P.Y.; Poulsen, L.K.; SchmidGrendelmeier, P.; et al. Precision medicine in patients with allergic diseases: Airway diseases and atopic dermatitis-PRACTALL document of the European Academy of Allergy and Clinical Immunology and the American Academy of Allergy, Asthma \& Immunology. J. Allergy Clin. Immunol. 2016, 137, 1347-1358. [CrossRef]

87. Brunner, P.M.; Silverberg, J.I.; Guttman-Yassky, E.; Paller, A.S.; Kabashima, K.; Amagai, M.; Luger, T.A.; Deleuran, M.; Werfel, T.; Eyerich, K.; et al. Councilors of the International Eczema Council. Increasing Comorbidities Suggest that Atopic Dermatitis Is a Systemic Disorder. J. Investig. Dermatol. 2017, 137, 18-25. [CrossRef]

88. Oliveira, C.; Torres, T. More than skin deep: The systemic nature of atopic dermatitis. Eur. J. Dermatol. 2019, $29,250-258$. [CrossRef]

89. Leung, D.Y.; Harbeck, R.; Bina, P.; Reiser, R.F.; Yang, E.; Norris, D.A.; Hanifin, J.M.; Sampson, H.A. Presence of IgE antibodies to staphylococcal exotoxins on the skin of patients with atopic dermatitis. Evidence for a new group of allergens. J. Clin. Investig. 1993, 2, 1374-1380. [CrossRef]

90. Totté, J.; de Wit, J.; Pardo, L.; Schuren, F.; van Doorn, M.; Pasmans, S. Targeted anti-staphylococcal therapy with endolysins in atopic dermatitis and the effect on steroid use, disease severity and the microbiome: Study protocol for a randomized controlled trial (MAAS trial). Trials 2017, 18, 404. [CrossRef]

91. Schmid-Grendelmeier, P.; Flückiger, S.; Disch, R.; Trautmann, A.; Wüthrich, B.; Blaser, K.; Scheynius, A.; Crameri, R. IgE-mediated and T cell-mediated autoimmunity against manganese superoxide dismutase in atopic dermatitis. J. Allergy Clin. Immunol. 2005, 115, 1068-1075. [CrossRef]

92. Flückiger, S.; Scapozza, L.; Mayer, C.; Blaser, K.; Folkers, G.; Crameri, R. Immunological and structural analysis of IgE-mediated cross-reactivity between manganese superoxide dismutases. Int. Arch. Allergy Immunol. 2002, 128, 292-303. [CrossRef] [PubMed]

93. Scala, E.; Abeni, D.; Guerra, E.C.; Pirrotta, L.; Locanto, M.; Meneguzzi, G.; Giani, M.; Russo, G.; Asero, R. $\beta-1,3$-glucanase rOle e 9 and MnSOD rAsp f 6 IgE reactivity are the signature of atopic dermatitis in the Mediterranean area. Clin. Exp. Allergy 2020, 50, 487-498. [CrossRef] [PubMed]

94. Valenta, R.; Mittermann, I.; Werfel, T.; Garn, H.; Renz, H. Linking allergy to autoimmune disease. Trends Immunol. 2009, 30, 109-116. [CrossRef]

95. Valenta, R.; Natter, S.; Seiberler, S.; Wichlas, S.; Maurer, D.; Hess, M.; Pavelka, M.; Grote, M.; Ferreira, F.; Szepfalusi, Z.; et al. Molecular characterization of an autoallergen, Hom s 1, identified by serum IgE from atopic dermatitis patients. J. Investig. Dermatol. 1998, 111, 1178-1183. [CrossRef]

96. Mittermann, I.; Reininger, R.; Zimmermann, M.; Gangl, K.; Reisinger, J.; Aichberger, K.J.; Greisenegger, E.K.; Niederberger, V.; Seipelt, J.; Bohle, B.; et al. The IgE-reactive autoantigen Hom s 2 induces damage of respiratory epithelial cells and keratinocytes via induction of IFN-gamma. J. Investig. Dermatol. 2008, 128, 1451-1459. [CrossRef] [PubMed]

97. Aichberger, K.J.; Mittermann, I.; Reininger, R.; Seiberler, S.; Swoboda, I.; Spitzauer, S.; Kopp, T.; Stingl, G.; Sperr, W.R.; Valent, P.; et al. Hom s 4 , an IgE-reactive autoantigen belonging to a new subfamily of calcium-binding proteins, can induce Th cell type 1-mediated autoreactivity. J. Immunol. 2005, 175, 1286-1294. [CrossRef]

98. Dzoro, S.; Mittermann, I.; Resch-Marat, Y.; Vrtala, S.; Nehr, M.; Hirschl, A.M.; Wikberg, G.; Lundeberg, L.; Johansson, C.; Scheynius, A.; et al. House dust mites as potential carriers for IgE sensitization to bacterial antigens. Allergy 2018, 73, 115-124 [CrossRef]

99. Nguyen, H.L.T.; Trujillo-Paez, J.V.; Umehara, Y.; Yue, H.; Peng, G.; Kiatsurayanon, C.; Chieosilapatham, P.; Song, P.; Okumura, K.; Ogawa, H.; et al. Role of Antimicrobial Peptides in Skin Barrier Repair in Individuals with Atopic Dermatitis. Int. J. Mol. Sci. 2020, 21, 7607. [CrossRef]

100. Niyonsaba, F.; Kiatsurayanon, C.; Chieosilapatham, P.; Ogawa, H. Friends or Foes? Host defense (antimicrobial) peptides and proteins in human skin diseases. Exp. Dermatol. 2017, 26, 989-998. [CrossRef]

101. Pahar, B.; Madonna, S.; Das, A.; Albanesi, C.; Girolomoni, G. Immunomodulatory Role of the Antimicrobial LL-37 Peptide in Autoimmune Diseases and Viral Infections. Vaccines 2020, 8, 517. [CrossRef] [PubMed]

102. Reinholz, M.; Ruzicka, T.; Schauber, J. Cathelicidin LL-37: An antimicrobial peptide with a role in inflammatory skin disease. Ann. Dermatol. 2012, 24, 126-135. [CrossRef] [PubMed]

103. Akiyama, T.; Niyonsaba, F.; Kiatsurayanon, C.; Nguyen, T.T.; Ushio, H.; Fujimura, T.; Ueno, T.; Okumura, K.; Ogawa, H.; Ikeda, S.J The human cathelicidin LL-37 host defense peptide upregulates tight junction-related proteins and increases human epidermal keratinocyte barrier function. Innate Immun. 2014, 6, 739-753. [CrossRef] [PubMed]

104. Lee, H.; Ryu, W.I.; Kim, H.J.; Bae, H.C.; Ryu, H.J.; Shin, J.J.; Song, K.H.; Kim, T.W.; Son, S.W. TSLP Down-Regulates S100A7 and ß-Defensin 2 Via the JAK2/STAT3-Dependent Mechanism. J. Investig. Dermatol. 2016, 136, 2427-2435. [CrossRef]

105. Hänel, K.H.; Pfaff, C.M.; Cornelissen, C.; Amann, P.M.; Marquardt, Y.; Czaja, K.; Kim, A.; Lüscher, B.; Baron, J.M. Control of the Physical and Antimicrobial Skin Barrier by an IL-31-IL-1 Signaling Network. J. Immunol. 2016, 196, 3233-3244. [CrossRef]

106. Fenner, J.; Silverberg, N.B. Skin diseases associated with atopic dermatitis. Clin. Dermatol. 2018, 36, 631-640. [CrossRef] 
107. Owen, J.L.; Vakharia, P.P.; Silverberg, J.I. The Role and Diagnosis of Allergic Contact Dermatitis in Patients with Atopic Dermatitis. Am. J. Clin. Dermatol. 2018, 19, 293-302. [CrossRef]

108. Gutin, L.; Tammaro, A.; Fishelevich, R.; Gaspari, A.A. Elevation of IL-9 in Extreme Patch Test Reactions Suggests It Is an Inflammatory Mediator in Allergic Contact Dermatitis. Dermatitis 2016, 27, 35-36. [CrossRef]

109. Koga, C.; Kabashima, K.; Shiraishi, N.; Kobayashi, M.; Tokura, Y. Possible pathogenic role of Th17 cells for atopic dermatitis. J. Investig. Dermatol. 2008, 128, 2625-2630. [CrossRef]

110. Nakae, S.; Komiyama, Y.; Nambu, A.; Sudo, K.; Iwase, M.; Homma, I.; Sekikawa, K.; Asano, M.; Iwakura, Y. Antigen-specific T cell sensitization is impaired in IL-17-deficient mice, causing suppression of allergic cellular and humoral responses. Immunity 2002, 17, 375-387. [CrossRef]

111. Milam, E.C.; Jacob, S.E.; Cohen, D.E. Contact Dermatitis in the Patient with Atopic Dermatitis. J. Allergy Clin. Immunol. Pract. 2019, 7, 18-26. [CrossRef]

112. Hamann, C.R.; Hamann, D.; Egeberg, A.; Johansen, J.D.; Silverberg, J.; Thyssen, J.P. Association between atopic dermatitis and contact sensitization: A systematic review and meta-analysis. J. Am. Acad. Dermatol. 2017, 77, 70-78. [CrossRef]

113. Ivert, L.U.; Wahlgren, C.F.; Lindelöf, B.; Dal, H.; Bradley, M.; Johansson, E.K. Association between atopic dermatitis and autoimmune diseases: A population-based case-control study. Br. J. Dermatol. 2021, 185, 335-342. [CrossRef] [PubMed]

114. Kusari, A.; Han, A.M.; Schairer, D.; Eichenfield, L.F. Atopic Dermatitis: New Developments. Dermatol. Clin. 2019, 37, 11-20. [CrossRef]

115. Yaghmaie, P.; Koudelka, C.W.; Simpson, E.L. Mental health comorbidity in patients with atopic dermatitis. J. Allergy Clin. Immunol. 2013, 131, 428-433. [CrossRef] [PubMed]

116. Sampogna, F.; Tabolli, S.; Abeni, D. Impact of different skin conditions on quality of life. G. Ital. Dermatol. Venereol. 2013, 148, 255-261.

117. Gómez, R.L.; Edgin, J.O. Sleep as a window into early neural development: Shifts in sleep-dependent learning effects across early childhood. Child Dev. Perspect. 2015, 9, 183-189. [CrossRef] [PubMed]

118. Paller, A.; Jaworski, J.C.; Simpson, E.L.; Boguniewicz, M.; Russell, J.J.; Block, J.K.; Tofte, S.; Dunn, J.D.; Feldman, S.R.; Clark, A.R.; et al. Major Comorbidities of Atopic Dermatitis: Beyond Allergic Disorders. Am. J. Clin. Dermatol. 2018, 19, 821-838. [CrossRef]

119. Vajdic, C.M.; Falster, M.O.; de Sanjose, S.; Martínez-Maza, O.; Becker, N.; Bracci, P.M.; Melbye, M.; Smedby, K.E.; Engels, E.A.; Turner, J.; et al. Atopic disease and risk of non-Hodgkin lymphoma: An InterLymph pooled analysis. Cancer Res. 2009, 69, 6482-6489. [CrossRef]

120. Brunner, P.M.; Suárez-Fariñas, M.; He, H.; Malik, K.; Wen, H.C.; Gonzalez, J.; Chan, T.C.; Estrada, Y.; Zheng, X.; Khattri, S.; et al. The atopic dermatitis blood signature is characterized by increases in inflammatory and cardiovascular risk proteins. Sci. Rep. 2017, 18, 8707. [CrossRef]

121. Ständer, S. Atopic Dermatitis. N. Engl. J. Med. 2021, 384, 1136-1143. [CrossRef] [PubMed]

122. Wollenberg, A.; Barbarot, S.; Bieber, T.; Christen-Zaech, S.; Deleuran, M.; Fink-Wagner, A.; Gieler, U.; Girolomoni, G.; Lau, S.; Muraro, A.; et al. Consensus-based European guidelines for treatment of atopic eczema (atopic dermatitis) in adults and children: Part I. J. Eur. Acad. Dermatol. Venereol. 2018, 32, 657-682. [CrossRef] [PubMed]

123. Ahn, J.; Choi, Y.; Simpson, E.L. Therapeutic New Era for Atopic Dermatitis: Part 1. Biologics. Ann. Dermatol. 2021, 33, 1-10. [CrossRef] [PubMed]

124. Wollenberg, A.; Barbarot, S.; Bieber, T.; Christen-Zaech, S.; Deleuran, M.; Fink-Wagner, A.; Gieler, U.; Girolomoni, G.; Lau, S.; Muraro, A.; et al. Consensus-based European guidelines for treatment of atopic eczema (atopic dermatitis) in adults and children: Part II. J. Eur. Acad. Dermatol. Venereol. 2018, 32, 850-878. [CrossRef] [PubMed]

125. Senner, S.; Seegräber, M.; Frey, S.; Kendziora, B.; Eicher, L.; Wollenberg, A. Dupilumab for the treatment of adolescents with atopic dermatitis. Expert Rev. Clin. Immunol. 2020, 16, 641-650. [CrossRef]

126. Chen, Y.L.; Gutowska-Owsiak, D.; Hardman, C.S.; Westmoreland, M.; MacKenzie, T.; Cifuentes, L.; Waithe, D.; Lloyd-Lavery, A.; Marquette, A.; Londei, M.; et al. Proof-of-concept clinical trial of etokimab shows a key role for IL-33 in atopic dermatitis pathogenesis. Transl. Med. 2019, 11, eaax2945. [CrossRef]

127. Traidl, S.; Freimooser, S.; Werfel, T. Janus kinase inhibitors for the therapy of atopic dermatitis. Allergol. Select 2021, $27,293-304$. [CrossRef]

128. Spinelli, F.R.; Meylan, F.; O'Shea, J.J.; Gadina, M. JAK inhibitors: Ten years after. Eur. J. Immunol. 2021, 51, 1615-1627. [CrossRef]

129. Markham, A.; Keam, S.J. Peficitinib: First Global Approval. Drugs 2019, 79, 887-891. [CrossRef]

130. Blauvelt, A.; Teixeira, H.D.; Simpson, E.L.; Costanzo, A.; De Bruin-Weller, M.; Barbarot, S.; Prajapati, V.H.; Lio, P.; Hu, X.; Wu, T.; et al. Efficacy and Safety of Upadacitinib vs Dupilumab in Adults With Moderate-to-Severe Atopic Dermatitis: A Randomized Clinical Trial. JAMA Dermatol. 2021, 157, 1047-1055. [CrossRef] 